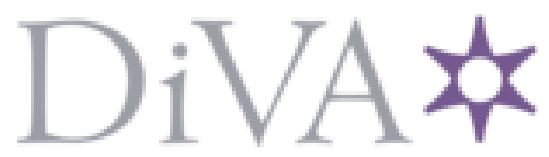

http://www.diva-portal.org

\title{
Postprint
}

This is the accepted version of a paper published in Geoforum. This paper has been peer-reviewed but does not include the final publisher proof-corrections or journal pagination.

Citation for the original published paper (version of record):

Power, D., Jansson, J. (2004)

The emergence of a post-industrial music economy?: Music and ICT synergies in Stockholm, Sweden..

Geoforum, 35(4): 425-439

http://dx.doi.org/10.1016/j.geoforum.2003.12.001

Access to the published version may require subscription.

N.B. When citing this work, cite the original published paper.

Permanent link to this version:

http://urn.kb.se/resolve?urn=urn:nbn:se:uu:diva-68767 


\section{"The emergence of a post-industrial music economy? Music and ICT synergies in Stockholm, Sweden."}

\section{Dominic Power* and Johan Jansson}

\section{Full Reference:}

Power, D. \& Jansson, J. (2004) "The emergence of a post-industrial music economy? Music and ICT synergies in Stockholm, Sweden”. Geoforum. Vol. 35, no. 4. pp. 425-439.

\section{Acknowledgements:}

The authors would like to thank the Nordic Industrial Fond for their support of this project and for the participants in the wider project "Behind the Music - Profiting from Sound: A Systems Approach to the Dynamics of Nordic Music Industry" for their input. Dominic Power would like to acknowledge the support of the European Community Marie Curie Fellowship under contract number HPMF-CT-200000668. We are particularly appreciative of the members of the many companies who were kind enough to give up their time to be interviewed and give us the information this paper is based upon. We would also like to especially thank the valuable comments of the anonymous referees, Andrew Leyshon, and Anders Malmberg. 


\title{
"The emergence of a post-industrial music economy? Music and ICT synergies in Stockholm, Sweden."
}

\begin{abstract}
Research into the music industry has for a long time been almost exclusively dominated by a focus on the production of albums and songs. In recent years, however, cities such as Stockholm have seen the growth of a profitable and varied music services industry producing everything from remixes to music marketing strategies. Standing at the forefront of this growth industry are a large number of firms attempting to combine in innovative ways music and ICT. This can take a variety of forms, for instance: selling and distributing music over the internet; web design and computerised advertising services tailored to music products; software design focused on multimedia products and virtual instruments; high-tech post-production and mixing services; and virtual centres and communities of music industry actors. The article will examine these activities within the city in attempt to measure the direction and cohesiveness of the emerging sector. The article concludes by arguing that these type of new industrial synergies tell us much about the way industrial innovations are formed in an interindustry and inter-cluster environment, and the future competitiveness and shape of the music industry. In particular, the article argues that evidence from Stockholm points to the emergence of a postindustrial musical economy.
\end{abstract}

Key words: music industry, IT and ICT, cluster, innovation, competitiveness, Sweden. 


\section{"The emergence of a post-industrial music economy? Music and ICT synergies in Stockholm, Sweden."}

\section{Introduction}

[p. 425] The music industry is a complex and continually evolving industry which has had a long history of not only musical but also technological innovation and change. Technological development has radically effected everything from musical instruments to the creation of new musical styles. Technological change has also had a key role in the development of the industrial structure of the music industry and the commercial and distribution possibilities open to the industry (Gronow, 1983; Lopes, 1992; Burnett, 1993; Frith, 1993; Christiansen, 1995; Cusic, 1996; Peterson and Berger, 1996; McCourt and Rothenbuhler, 1997; Jones, 2002). The development of cheap and easily mass produced vinyl records radically changed the mass market possibilities open to the music industry and forced a radical restructuring of the industry itself (Wallis, 1990; Wallis and Malm, 1990). Similarly in recent years pundits and academics alike have suggested that ICT-based advances such as the internet and new audio file formats (e.g. MP3 files) are laying the road to a new era for the music industry (Haring, 2000; Cooper and Harrison, 2001; Kretschmer et al., 2001; Leyshon, 2001; Merriden, 2001; Shirky, 2001; Alderman, 2002; Alexander, 2002; Ku, 2002; Menn, 2003). Indeed, most of the current debate and literature on the new technologies supposedly forcing a restructuring of the industry are entirely focused on the distribution of music through the internet: whether it be virtual CD shops or the illegal distribution of music as compressed computer files across the internet: e.g. using technology such as Napster or Gnutella (Leyshon, 2001; Shirky, 2001; Alderman, 2002; Alexander, 2002; Leyshon, 2003 Forthcoming). These type of activities obviously have crucial implications for the music industry's business model, which is still one involving the mass distribution of large amounts of moulded plastic. In particular the five global music 'majors' that dominate the global music industry see such developments [p. 426] as especially threatening not only to their ability to collect on their own copyrighted product but also their profitable and strategically useful domination of physical distribution networks. Whilst new technologies are not the only threat to sales of recorded music (the rise of DVDs and video games are increasingly competing for consumers' spending) and it is unclear whether such technologies are a permanent threat to recorded music it is clear to see that global sales of 
recorded music have in recent years been steadily declining. In 2002 world sales of recorded music fell by $7 \%$ in value and by $8 \%$ in the number of units sold following similar falls in 2001, 2000 and 1999. These trends have been particularly heavy in the world's two largest markets (that together account for $55 \%$ of global sales): in 2002 US unit sales fell 10\% and Japanese sales fell by $9 \%$ (IFPI, 2003).

It is against this background that this article reports on the findings of a research project into the ways in which new information and communications technologies (ICT) are being combined with music by firms based in Stockholm. The purpose of the study, and this article, was to examine the development of ICT-music activities using exploratory data from Stockholm. In particular an attempt is made to understand the parameters and dynamics of these new activities and to question their relationships to existing music and ICT industries. Underlying this was a further concern to understand how such activities fit into the likely evolution of the music industry and economy.

In addition to presenting material on a relatively unstudied emerging area of the economy and music industry, the article addresses what the authors' consider to be two pressing issues: the very limited idea that academic and popular studies of music have had of what the music industry involves; and a relative lack of empirical studies of the effects of having a leg in more than one strong cluster. If we think in terms of, for example, an industrial systems approach we can see that the production of music products involves a variety of inputs and agents (sometimes collaborative, sometimes bitterly competitive) all of which are intrinsic parts of the 'creative' process which must be understood as essentially rooted in an industry based commercial logic that is often highly spatialised (Frith, 1991; Leyshon et al., 1998; Negus, 1998; Scott, 1999a; Hallencreutz et al., 2000; Hallencreutz, 2002). Literature on the music industry tends to overwhelmingly focus on artiste and record company centred views of the music industry and musical products. They focus on the process of musical creation (e.g. forming a band), the manufacture of a sellable product (e.g. signing a record contract that leads to large numbers of plastic discs being produced) and the eventual consumption of the finished product by fans/consumers; a story in which centres of production (Hesmondhalgh, 1996; Scott, 1999a; Scott, 1999b; Scott, 2000b) and global record companies (Wallis and Malm, 1984; Firth, 1992; Hirsch, 1992; Malm and Wallis, 1992; Shapiro et al., 1992; Choi and Hilton, 1995; Alexander, 1996; Burnett, 1996; Sadler, 1997) have always had important roles. Whilst this artiste and record company focused process is undoubtedly the core of the music industry's activities and remaining profitability it is a focus which tends to leave out many of the related industries and activities that can be considered parts of a music 
industrial system. In particular, the artiste centred approach tends to treat activities such as songwriting, video production, merchandising, post-production, etc. as entirely dominated by and purely derivative of the core artiste-record company production axis. Although in many ways this is true, such a focus neglects the fact that a successful music industry in a certain place or region need not actually produce music. Such a view denigrates the important role played by related and service firms that are relatively independent of artistes and record companies in both the music industry and regional economies. The stress we place in this article on the growth of an independent musical services economy we hope will contribute to better understanding music as an industrial system with a variety of inputs and outputs. The article concludes by suggesting that such activities illustrate ongoing phenomena important to the future shape of the music industry. In particular, we argue that the music industry is rapidly moving away from a business model based on intellectual property rights contained in recorded music to one where a 'post-industrial' (Bell, 1974) musical economy exists: an economy where the value added and profits are to be found in information, service and related activities rather than manufacture.

Secondly, despite a rush of empirical studies into industrial clusters and cluster-based policy initiatives most studies tend to limit themselves to what is happening within industrial clusters (Bathelt et al., 2002; Malmberg and Maskell, 2002; Martin and Sunley, 2003; Power and Malmberg, 2003; Malmberg and Power, 2003). Research has mainly focused on the issue of whether or not being within an industrial cluster has positive effects or not for firms. However, Porter, amongst others, has drawn attention to the idea that commercial innovations appear not only within industrial clusters but most often at the intersection of existing clusters and sectors (Porter, 2001): innovation is here defined in a broad sense, as the ability to come up with new and better ways of organizing the production and marketing of new and better products (Porter, 1990; Lundvall, 1992; Nelson, 1993; Nonaka, 1994; Grant, 1996). Nevertheless, few empirical studies have addressed the issue of the way industrial innovations are formed in an inter-cluster environment: i.e. what is happening between two (or more) already established clusters in relation to new business activities and innovations [p. 427] that borrow from both. Thus this article attempts to contribute to empirical evidence on how new business innovations are effected by proximity to and relations with strong and well established clusters; using the example of emerging ICT-music synergies in Stockholm. The article concludes by suggesting that 
there exists strong evidence to oppose or unsettle commonly touted and held beliefs that clusters or localised industrial systems are best for innovation and emerging firms.

The article starts by introducing the case and research project, and by outlining the types of activities mixing ICT and music. Following this evidence and conclusions from firms based in Stockholm is presented along four themes that emerged from research.

\section{An emerging post-industrial music service economy? The case of music and ICT synergies in Stockholm.}

Stockholm has a relatively strong, export oriented music industry characterized by a large number of both local and global music firms engaged in the commercial exploitation of music, and the creation of musical acts that have enjoyed some measure of international success: such as Abba, Ace of Base, the Cardigans, Neneh Cherry, Europe, the Hives, and Roxette. However, in recent years it can be seen that activities traditionally thought of as peripheral to a music industry have been accounting for increasingly large portions of Swedish 'music' exports. The success of Stockholm based songwriters (who have written songs for international artists including The Backstreet Boys, Bon Jovi, Britney Spears, Celine Dion, and N'Sync) and video producers (who have produced videos for international clients such as Iggy Pop, Madonna, Metallica, and U2) in particular has drawn attention to the idea that the Swedish music industry does not need to rely purely on home-grown bands (Forss, 1999; Forss, 2001; Forss and Podolieva, 2002; Hallencreutz, 2002; Power and Hallencreutz, 2002; Braunerhjelm and Helgesson, 2003). Increasingly there is an awareness that a successful music industry can be based on providing specialised services that can be sold across the globe; and that these services are increasingly the most profitable areas of the musical value chain. In the conclusion and below we argue that as the album sales decline and copyrighted material becomes increasingly impossible to protect something akin to the decline of manufacturing industry in Western countries may happen. In short that it will be innovative service based and often ICT mediated elements of the musical economy that the largest profits and value added will reside: that a post-industrial musical economy may arise. These activities and companies which are treated below give, we think, evidence of the likely evolution of a new musical economy. 
The primary purpose of this article is to explore the development of ICT-music activities. In order to do so a study was made of all the Stockholm firms that had ICT-music activities as their main business focus (see further below for a fuller explanation of what these activities are). An examination of various industry sources and Swedish company registry records and databases revealed that there were just over 100 commercially active firms working in this area in Stockholm. In addition many hundred non-commercial sites and activities were found. However, we chose to focus on the commercially oriented actors and conducted face-to-face (and some telephone) interviews with around 25 companies and relevant industry organisations during the course of the second half of 2002. Those interviewed were all in senior positions within the firms and mostly the founders of the firms. All but one was male: this reflects the overwhelming male bias at managerial level in the Swedish music industry (Hallencreutz, 2002). The firms that the interviewees worked within were all small firms with less than 40 employees; with the exception of one firm which was a fully owned subsidiary of a large multi-national media conglomerate. Industry organizations, collecting agencies and support bodies were also surveyed and interviewed. One weakness of the study is that it largely, though not entirely, excludes those sections of, or departments within, larger media, music, and ICT firms that may be engaged in the same type of activities. However, in our defence: these are mostly relatively new business areas and dominated by small start-up 'pioneers'; and the small firms studied were often owned or part-owned by the larger music, media and ICT industry players. A further methodological issue worth mentioning is that the paper should be seen as an exploratory piece and that it is built upon material from interviews with people within the industry. This was unavoidable as the novelty of the activities meant that almost no external literature was available and that the companies themselves had to be relied upon for all information. A number of problems and biases can arise from such a foundation in qualitative research based on the interpretation of the voices of positioned actors (McDowell, 1992; Smith, 1993; England, 1994) and from corporate interviewing (Schoenberger, 1991; Clark, 1998) but it was hoped that cross referencing of materials and the researchers 'objectivity' checked as much as possible of such bias.

What emerged from research was that the emerging 'sector' is a rather confused mélange of firms and activities that despite sharing music as their core business focus and product tend to have little in common. In addition, firms dealing in the conjunction of music and ICT are relatively new; the majority of the firms in our survey were no more than three years old which means that exact growth 
rates and trends are rather unreliable (though the fact that of our firm sample [p. 428] only two were older than two years indicates the 'growth' of this activity area). The impact of the bursting of the ICTbubble also meant that during the research project some firms collapsed (though none of the firms interviewed). It is not therefore our purpose to say that a new cluster of activities or a fully functioning independent industrial system now exists in Stockholm nor to claim that these firms have produced an enormous fountain of success, revenue and employment. Rather the aim below is to present what were identified during the research project as the key factors/elements in the particular growth of these activities in Stockholm.

As mentioned earlier the literature on ICT and music is almost entirely focused on on-line distribution methods, however, our research found that ICT does not only have implications for the selling and distribution of music and at present it may be said that firms working with ICT-music crossovers fall into five rough categories.

1. Firms focused on internet-based music sales and distribution: ranging from on-line retailers of traditional music media (such as CDs) to firms distributing new digitalized formats of music through the internet or mobile telephones, etc..

2. Web design and advertising services tailored to musical products: firms working on the design of and infrastructure behind new ways of advertising and communicating to music customers through the internet or mobile devices.

3. Software programming and design focused on online or multimedia products and virtual instruments.

4. High-tech post-production and mixing services: for instance firms using (new) digitalised technology in the recording and mixing phase, and digitalised post-production phases such as video and sound mastering.

5. Virtual centres and communities for music industry actors and new ways of communicating, mainly through internet with customers, but also with other actors within the music industry. Apart from the first category these activities are extremely under-researched: largely due perhaps to the fact that the technology and market for some of them has only lasted a few years. The rest of the paper will deal with firms working in these five areas. Rather than presenting a section on each of the above five we will, following the next section, draw on all of these five activity types to exemplify four main themes that emerged from the research: the ways in which new technologies give 
rise to new opportunities; the role of relationships with existing industries; the role of agglomeration effects and economies; and the development of new business ideologies.

\section{New technology, new opportunities?}

We have already outlined many of the new technologies and applications that characterize this emerging area of activity. These new technologies can be divided into two categories: doing old things in new ways; and doing completely new things.

As noted earlier the music industry has in its history constantly adjusted to new types of media and technology. In particular new technology has most heavily effected the type of medium on which music can be stored, sold and distributed. Much of the new ICT-driven technological advances in music seen in the Stockholm study conform to this type of activity. The prime examples of this are firms distributing/selling music in computer file formats (such as MP3) or selling traditional products over the net. Whilst relying on completely new distribution methods, channels and technology, these firms essentially retain the same business idea as their predecessors and 'real world' competitors: i.e. making money from copyrighted material produced and distributed to a mass-market. In Stockholm it is small new firms that are pioneering this field of activity. Indeed the major record labels/distributors that dominate the traditional music market (sales of CDs) are increasingly wary of internet distribution and sales and many of the largest (such as the German giant BMG) have begun closing their own internet operations or making increasing use of alliances and sales deals with e-commerce firms, etc. The established music companies and distributors seem reluctantly willing to leave these activities to existing book and record retailers and the new start-ups. This may be explained by the fact that at present relatively little profit is to be had from the low sales volumes involved in online music and the expense of distributing high quality music products online (bandwidth costs for sending a quality sound recording to the consumer still far outweigh the unit costs of producing, packaging and shipping mass produced CDs). Though of course this situation may be subject to rapid change in the future.

Although many firms were engaged in net-based music distribution two examples of doing old things in new ways will be briefly treated here: ring-tones; and instrument manufacture.

In Sweden and Scandinavia (and indeed the rest of the world) the last year or so has witnessed an explosive growth in sales of mobile telephone (cell phone) ring-tones (known in many European 
countries as ring-signals). The idea here is simple: you ring a number or access a website and buy a tinny sounding version of your favourite melody that is installed on your mobile telephone and is 'played' when your phone rings (to the great amusement/annoyance of those in close proximity). During 2001, 25 million ring tones were downloaded in the Nordic countries (STIM, 2001) at a cost [p. 429] of between around US\$1-2 per downloaded ring-tone plus a small administrative fee. In 2000 the total sales of music singles (CD and vinyl) in the five Nordic countries amounted to 8.8 million units (IFPI, 2001). Both numerically and in light of continually declining singles sales ring-tones have come to represent a major music market with all the characteristics of the old-style singles markets: ring-tone operators provide their customers with the latest melodies (one company interviewed, INPOC, estimated that $90 \%$ of it sales come from new releases; analysis of the ring-tone charts put this at between 80 and 90\%); charts and hit lists are produced (and appear, for instance, in the Swedish music industry magazine Musikindustrin); and ring-tones are widely seen by the music industry as both a growing revenue source and as good advertising for new artists and albums.

The Swedish ring-tone industry is comprised of around 20 firms, of which there are six dominant firms. Seven of these are directly owned by or subsidiaries of foreign firms, and the majority are part of larger concerns (in particular media groups, telephone operators, newspapers, and television stations) that have other products as their principal activities. Typically the firms make/program the ring-tones themselves or buy them in from foreign suppliers (which are often part of the same larger concern). However, producing the tone program itself is a relatively simple process and it is in distribution/delivery and in advertising/market placement that most of the firms' energies are spent and employees engaged. Responses revealed that the most important actors for the ring-tone firms were the print and broadcast media channels they advertised their products in. The firms clearly thought of themselves as essentially suppliers of mobile telephone services the content of which is relatively unimportant (as long as it sells) and decided by other industries and activities: primarily the music and film industries. Thus despite relying on the music industry's production and commercialisation of songs and artists they have no direct involvement or interaction with music industry firms; except for cooperation with the various collecting agencies royalties must be paid to.

When ring-tones first started appearing a few years ago there was a problem with firms selling or distributing them without licensing deals and without paying royalties. However, as the industry has gathered prominence the initial wholesale piracy has been largely eliminated. In Sweden this has 
mainly been the work of the copyright collecting agency STIM (the Swedish Performing Rights Society - the agency that collects royalties owed to composers and lyricists) who were extremely active in clamping down on illegal activity and unpaid royalties. Composition copyright payments are now paid to the order of $10 \%$ of the retail price of a ring-tone with a minimum of 1 Swedish krona (about 10 cents US) per unit. For songwriters and music publishers this is a very attractive deal. Normal royalty payments on singles in the USA are between 10-14\% (see Passman 1997) and in Sweden these payments currently stand at $7.4 \%$ of the retail price, or 1.1 Swedish krona (around 11 cents US) per song on a multi-track single. However, it is crucial to note that this is only paid on perhaps $75 \%$ of the units sold (as royalties are not paid out on the large numbers of free copies and discounts record companies and distributors grant retailers) which are in any case substantially lower than the number of ring-tones now sold to consumers.

In many ways this new form of ICT mediated music allows for easier and better copyright protection than that currently afforded to traditional media. Mobile phones are currently rather difficult to reprogram or download new software, such as ring-tones, onto thus limiting the potential for 'file sharing' type infringements. Also it is easy for instance for ring-tone operations to be monitored due to the cooperation of network operators and due to the small number of major actors (12 in Sweden) and their high profile advertising. Furthermore the high degree of competitiveness in the industry means that the companies selling ring-tones monitor each other and are more than happy to report competitors' infringements or royalties lapses (they don't want their competitors having lower costs than they have).

"If we discover a competitor who has not paid [royalties] and therefore can have lower prices or costs than us then of course we will mention to STIM [the copyright collection agency] that they should investigate that competitor. So it becomes kind of self regulating." Kristin Hjuland, INPOC AB, 8 August 2002.

The ring-tone market then closely resembles the early stages of the vinyl singles market which both grew rapidly and was relatively easily guarded from piracy (due to the difficulty in pressing/copying vinyl). Just as the diffusion of new technology such as cheap record players caused a singles sales boom for record companies the introduction of new polyphonic (high quality ring-tone) telephones are widely predicted to further expand the nascent ring-tone market. Indeed the introduction 
of new phones capable of playing specific artistes' versions of songs will mean that not only the melody writer but also the performer can use this new technology as a revenue source.

A second example of a new method of doing something that has long been an integral part of the music industry is the business of developing and selling virtual instruments. These type of instruments are based on computer programmes and are made for computer use only. Normally such products are a combination [p. 430] of synthesizer and drum machine in a virtual form; this means that the product can be released and distributed through the Internet or sold on a CD. They can, however, take other forms such as those services provided by firms specialising in composing and providing the 'instruments' most commonly used in genres such as dance, hip hop, and rap: samples. Whilst developing and selling virtual instruments is quite a small business with only limited numbers of firms worldwide some interesting and successful firms were found in Stockholm. In terms of 'pure' virtual instruments Stockholm-based Propellerheads (www.propellerheads.se) have since their founding in 1997 become one of the world's leading suppliers of (award winning) virtual instruments such as Reason and ReBirth. Other types of 'instruments' oriented towards professional musicians and producers include subscription services for original composition 'sample' material pioneered by Stockholm firms such as Primesounds (www.primesounds.com). Activities such making virtual instruments extend the definition of what is commonly thought of as the core of the music industry but are, of course, central to the experience and performance of music. Indeed a common impression held by those interviewed was that active involvement in music, rather than just buying CDs, had increased dramatically.

"These related industries, those that don't sell CDs, those that work with for example tours or the sort of thing we or Steinberg [a German virtual instruments manufacturer] do... interest in them and in music has increased even if record sales have not risen proportionally. Anyone with a computer can get a cracked Cubase [Steinberg's virtual instrument software] sit down and start creating music. More and more are making music themselves... it's an interest and they spend money on it even if it never becomes a record. This type of thing has grown enormously: not just buying music but making it yourself.” Niclass Björlund, Primesounds AB, 28 August 2002 .

Whilst these firms deal in relatively small revenue volumes, niche markets and are traditionally viewed as of only sideline interest to the music industry, the companies' response to the 
ease of which their products have always been pirated holds clues of wider significance to the music industry as a whole. Interviews revealed that the firms thought it impossible and wasteful, especially in the long-term, to attempt to copyright protect computerised products; instead the firms have attempted to build 'communities' around their products that can only be accessed by registered users (Tang, 1998; Gordijn et al., 2000). Firms' attempts to establish 'community relations' surrounding their products is a classic survival strategy not just to add value but to avert risk: a strategy of using associations, alliances, and network relations in order to help manage or offset risk (Banks et al., 2000).

“There exists enormous numbers pirate copies of our programs out there... There are two ways to deal with this. One is the stick the other is the carrot. The stick in our case is embedded copy-protection software. We have a copy protection but it is rather mild, not that tough. For instance one can easily copy our disks. Instead we have gambled everything on the carrot and this is why we use our website a lot. The carrot is to do with giving folk as many reasons as possible to register the product. And what they get when they register, they get tech support, they get add-on programs, they get more sounds, they get the possibility to download from our song archives and above all lots of free stuff such access to other sites which includes sounds compatible with our program. It is in this type of way we try and solve the problem: we try and build loyalty.” Ernst Nathorst-Böös, Propellerheads AB, 15 August 2002.

These virtual communities attempt to inspire loyalty through giving users access to additional products, add-ons, plug-ins, updates, etc. (just as fanzines, fan clubs and many independent bands and retailers have long done) but also with a chance to communicate directly with other musicians using the software. These communities also function as very effective customer feedback forums and can result in valuable $R \& D$ work when users develop solutions to bugs, etc. The 'instrument' makers have also used these communities as profitable marketplaces for related products such as merchandised bags and clothing. Interviews revealed that such community building is a difficult process as it is easy to alienate the customer or create areas inappropriate to their tastes and (sub)cultures. In the 'proper' music industry some artists and record companies have begun to attempt such community building as a way of enticing consumers into buying a legal copy and promoting tours and merchandise; but they are relatively new to this type of activity and could learn much from the long experience of the companies talked about above. 
New ICT has, of course, created entirely new types of business activity. Some examples of such activities found during the research period were: website designers specialising in music; specialists in digital encoding of music and music video; multimedia, DVD, and Super Audio CD mastering and postproduction services; specialist providers of streaming music and copy protected samples to e-tailers; SMS (mobile telephone text messages) and webcast services tailored to music events, festivals and tours; streaming music video and radio channels; and an online and on-demand music video service with the world's largest archive of music videos.

[p. 431] In essence all these new activities seem dependent upon the existence of a mass consumption market for music and to a large extent the production and selling of CDs. The mass music market has long been dominated by the powerful global record companies who have the power to 'break' an act onto the public consciousness (Burnett, 1996; Sadler, 1997; Negus, 1999). What is interesting about the companies we studied in Stockholm is that whilst dependent upon the existence of the 'traditional' music market and industry, the current firm structure and organisation of the mainstream music industry does not have a central effect on their business (though 'major' and 'independent' record companies are often important clients or backers and, as will be discussed later, most of the staff have a record industry background). They are in effect flexible service and infrastructure providers to the music industry and market. Importantly they can be seen to be extending the range of 'add-ons' that can be associated with the core musical product: the $\mathrm{CD}$ and artiste. If we think, for example, of live music there are a growing range of add-ons such as pay-per-view 'webcasting' of the concert and in-hall SMS message boards and virtual meeting places that are rapidly becoming profitable extras to artistes' and promoters' traditional live revenue sources - sales of tickets, warm beer, and badly printed t-shirts.

"I think the key to the music industry is the possibility to sell the brand in more ways than just with the record. In the sports world they have done this for a very long time... And in the music world there is no merchandise, that only really exists at concerts and is most often done in deals between the promoter and half illegal t-shirt printers. And merchandise I would not hang my hopes on to save the music industry. What I think the record companies are going to want and soon going to insist on in their contracts with artists, is more rights than today are controlled by the record companies. So maybe it will be the record company that negotiates promoter rights and concert revenues, that they have the rights to make merchandise, and if an 
artist is called Christina Aguilera and does a deal with Pepsi for 40 million dollars the record is there and takes its share.” Ludvig Werner, Fame Studios AB, 28 August 2002.

Music-ICT activities share the characteristic that they are developing new opportunities and/or channels for adding value to the core product and extracting the maximum from the rights that do exist. This is especially important to the profitability of an industry whose core product - the album - is under severe pressure from the end of the CD replacement market, the negative substitution effects of the rise of DVDs, CD burning/copying and internet piracy.

While an attempt has been made to disentangle these new activities it was clear from the research that many of the firms themselves are attempting to combine as many of these activities or services under one roof as possible. Many of the firms are attempting to style themselves as one-stop providers of music-ICT products, or at the very least instituting relatively formalised cooperative links with other ICT-music firms. This has had the effect of giving some sort of a cohesive identity to the activities; though not yet to the extent that they may be easily labelled a sector or sub-sector.

\section{A branch to hold onto?}

A second key factor in the evolution of music-ICT firms was seen to be the relation of the firms to existing industries: principally the music industry and the ICT industry. The development patterns of new economic activities, and indeed firms, are greatly determined by the relations between the 'old' and 'new'. One may imagine that new business areas and innovations will stand a better chance of success if they can draw on the networks, channels, capital, and knowledge, etc. of an established industry. This sort of viewpoint has gathered increased prominence in recent debates about the positive nature of clusters (Malmberg et al., 1996; Porter, 1998; European Commission and Federation of Austrian Industry in Styria, 1999; OECD, 1999; OECD, 2001). In the cluster perspective innovative and supporting activities find a nurturing environment in the dense interconnectedness of a functioning industrial cluster. Alternatively one may think of a situation in which the close proximity of an existing industry with powerful and competitive vested interests can work to marginalize, usurp or hold-back innovative firms or products. In other words, being a part of, or in close proximity, to a well-developed 
cluster of successful firms may for small firms in fact principally mean exposure to well-trained and financed competitive predators.

If we take a 'cluster' to mean an industrial system with a specific geographic agglomeration and a unifying discourse, identity or brand (for a fuller description of this problematic concept see: (Malmberg, 2002; Malmberg and Maskell, 2002; Martin and Sunley, 2003) both the music and ICT agglomerations in Stockholm can be described as 'clusters' (Braunerhjelm and Carlsson, 1999; Sandberg, 1999; Berggren, 2000; Birkinshaw, 2000; White and Coronado, 2000; NUTEK, 2001; Hallencreutz, 2002; Power and Hallencreutz, 2002). They both share some defining 'cluster properties' (Lundequist and Power, 2002): they are geographically agglomerated; exhibit intensified internal transactions; have well developed institutional frameworks and cluster [p. 432] organisations; specialised labour forces and training/educational schemes; developed cluster-brands and marketing operations; identifiable social networks; and some level of group consciousness (and sometimes 'cluster'-consciousness) amongst industry workers and actors. In many ways then both ICT and music in Stockholm can be considered identifiable clusters with relatively defined borders. Nonetheless the borders are extremely fluid and the companies involved in each 'cluster' regularly interact and do business with a wide variety of other sectors, types of firms, and customers and collaborators that are not located in Stockholm.

The growth of a music services industry in Stockholm has much to do with the fact that the city is the centre for the highly centralised or agglomerated Swedish music production system (Statens Kulturråd, 1998; Almquist et al., 1999; Forss, 1999; Almquist et al., 2000; Hallencreutz, Lundequist and Malmberg, 2000; Jansson, 2000; Johansson, 2000; Statens Kulturråd, 2000; Hallencreutz and Lundequist, 2001; Lundequist and Power, 2002; Power, 2002; Hallencreutz et al., 2003) which after the US and UK is one of the largest net exporters of popular music products (Burnett, 1997; Forss, 1999; Forss, 2001; Forss and Podolieva, 2002; Power, 2003). Stockholm has many both local and international music companies: around 200 record companies and around 70 music publishing companies (Power and Hallencreutz, 2002; Power, 2003).

Also centred in Stockholm is the heart of Sweden's ICT-sector which consisted in 2001 of around 36,500 firms and upwards of 247,000 employees. That represented approximately almost six percent of the Swedish workforce. If one excludes electronics manufacturing the ICT-related service sector could be said to consist of over 34,600 firms and 175,500 employees in 2001. It is well 
documented that the ICT-related service sector tend to concentrate in big cities and densely populated areas (Brail and Gertler, 1999; Pratt, 2000; Zook, 2000). The same pattern is found in Sweden (Birkinshaw, 2000; White and Coronado, 2000) with 46\% of employment within the ICT-related service sector and $38 \%$ of the firms located in greater Stockholm. Elements of this sector that are closest in business area to our study firms exhibit an even higher penchant for Stockholm with over $50 \%$ of the entire country's new media and internet firms and employees in central Stockholm (all figures from ITPS [Swedish Institute for Growth Policy Studies] website 15 November 2002: http://www.itps.se).

In Stockholm it appears that the firms we studied have experienced both negative and positive effects emanating from their proximity to both the city's well established music cluster and ICT and mobile-telecommunications cluster.

All our respondents reported having important links to one or both of these proximate clusters/agglomerations. Commonly reported links or inheritances included: sectorally based social networks; early career experiences; imported knowledge and contacts; sectorally focused or located venture capital sources; and supporting industry organisations. For the most part firms interviewed cited the music industry as their key source of inspiration, experiences, and staff. In most cases, the interviewee had her/his training and start from the music industry.

"There are a lot of people who have come from Compaq, Microsoft, telecoms operators, Telia in order to be in the music industry and make themselves a little flashier, and all have failed, but it has worked much better in the other direction. People have left the record companies and done extremely well in net and media companies.” Anders Hjelmtorp, Musicbrigade AB, 12 September 2002.

However, these experiences of, and often very emotional connections to, the music industry were generally tempered by a strong interest in, working experience of, and great knowledge of both ICT-technologies and industry. Most importantly a majority of the firms said that their suppliers, customers, funding/venture capital, and/or target market came from the ICT sector (in the broadest sense). It is also interesting to note that not all the technology these firms use is that uncommon or specialized (like for example streaming music for the internet) nor are they that difficult to master and thus people working with them do not necessarily have to have high levels of technical skill. In this case the firms' competitive advantage was embedded in the way they used the technology combined 
with a feeling, or fingerspitzengefühl, derived from the music industry. However, some aspects of music and the brands and consumption practices/cultures that go along with it are complex things often requiring very high levels of skill. Encoding sound into a digital form, for instance, is both a highly technical as well as highly nuanced and artful process. In cases where codified knowledge exists everywhere it may become valuable if it is compounded with less universal knowledge embedded in, or learned within, the local milieu in tacit forms (Asheim, 1999). Thus one can say that in terms of inspiration, experience and staff the music industry link was the strongest but in terms of suppliers, customers, capital and markets the link to ICT was slighter stronger.

Aside from aspects of training and knowledge many firms had very material connections to one of the established clusters. A good example of a firm depending on the existing music industry for their customers and culture is Cutting Room (www.cutting-room.se), a firm focusing on digital (and analogue) post-production, primarily mastering. Mastering involves both the harmonization of the 'sound' on an album - tracks on an [p. 433] album are often recorded at a number of different studios or using different technicians and machinery so their sound quality and feel can be very different - and putting the final touches to the sound is a highly specialised business with each mastering studio, led by their chief 'technician', having a highly individual style or 'sound'. When the firm started in the mid 1970s they depended entirely on their close relations and proximity to Swedish record companies. Over time they have became globally recognised for a particular 'sound' and high quality equipment and products. Today over $50 \%$ of their business is with international artistes who come to the firm's studios to master their albums from as far as Japan and the USA.

A contrasting example is the firm Digfi (www.digfi.com) which has a two year old web-based music news and retail site. Though financed by one of the country's largest industry organisations (SAMI - Swedish Artists' and Musicians' Interest Organisation) it was not allowed by the major labels to distribute or sell their catalogues: most likely because at the time all the majors were developing their own on-line operations and wanted to limit competition. As a result it had to change its business model (and profit expectations) to concentrate on news, promotions, competitions, independent labels and unsigned acts. This is a not uncommon example of the power the major record companies have over the distribution and retail of music which they use to limit the number of players and retail methods in the market. In general it seems that the nearer firms get to the traditional music industry operations and market areas - promoting, distributing and selling musical intellectual property rights - 
the greater the effect of the industrial structure and operations of the existing cluster, and the majors that dominate it, were felt.

The existence of a strong ICT industry no doubt gave a great initial boost to many music-ICT firms who, in the mid to late $1990 \mathrm{~s}$, found it easy to access large amounts of venture capital. In addition most of the companies interviewed had staff with ICT rather than music backgrounds or often hired in locally sourced ICT expertise. In Stockholm companies involved in the afore mentioned ring-tone business have been particularly well supported by the existence of a large agglomeration of wireless technology firms (Stockholm is often dubbed 'wireless valley') as well as a population with one of the world's highest levels of mobile phone usage and penetration (OECD, 2000; OECD, 2002). This has meant that highly developed R\&D facilities and expertise, test markets, and specialized venture capitalists exist to help start-ups.

However, with the dot.com crash and the downturn in the global ICT market many of the firms that positioned themselves more within the ICT industry than the music industry found themselves drawn into the tumult effecting the ICT industry. In several cases this resulted in loans/venture capital being called in and liquidation. However, it must be noted that the misfortunes of some firms have benefited others: for instance, one of the firms interviewed Famestudios (financed and owned by music industry celebrities such as ex-ABBA members - www.famestudios.se) suddenly found its venture capital-laden competitors exit the stage with the ICT crash. Although financed by music industry stalwarts this company does most of its business - event management including internet and mobile phone services and broadcasting - with clients from ICT and non-music sectors. This example shows that full structural and capital integration into one cluster can be a risky strategy in uncertain times and its continued existence is due to its straddling of two separate business realms.

It became apparent from interviews that a further factor related to identification with a strong sectoral cluster was the role of sectoral understandings of the future and market possibilities. During the period of study the ICT sector in Stockholm was suffering heavily from stock market crashes and a lack of investor confidence. Interviewees reported that this meant firms and investors were unwilling to support unproven activities: such as ring-tones or music oriented web-products. Likewise in the music industry a general perception that the global music market was shrinking meant that the mainstream of the industry were dealing with increased risk by slimming down operations and concentrating on product ranges with well-proven track records: such as compilation albums, re-releases, and mass 
market pop products. Within the music-ICT firms this was seen to be causing the mainstream of the industry to be unwilling to concentrate on anything other than high-volume CD sales. ICT-music employees suggested that the growth of such dominant understandings of what the music market should be had made record companies blind to the opportunities presented by new distribution formats: in particular ring-tones. This may explain why ring-tones have been understood by record companies as merely novel adverts that may help lead consumers to the real product: singles and albums. This has left the growing ring-tone market almost entirely open to new media and telecoms firms that have no cultural or organisational links to the music (or indeed ICT) industry, even though they may deem such connections desirable.

"We are a contents provider. We cannot of course be defined as an IT firm though we have a website and work lots with the internet... We fall outside those different networks since we aren't in the music business, not an IT company and not a pure media firm... Though I would wish we were more involved in those networks. " Kristin Hjuland, INPOC AB, 8 August 2002.

[p. 434] Such feelings of separateness from both the ICT and music industries were found in several other of the firms. However, not all respondents thought the lack of connection between their worlds and those of the other industries were a disadvantage.

"What many people who don't know us believe is that we should have strong links to the record industry, but we don't at all... We have never felt it necessary to have closer links to the record industry" Ernst Nathorst-Böös, Propellerheads AB, 15 August 2002.

This study then suggests that a crucial factor in the type of pressures firms engaged in new or innovative activities that cross established industrial boundaries is how they have positioned themselves vis-à-vis existing industries. It is by no means true to say that being firmly within, or sharing characteristics with, established proximate industrial clusters always benefits new firms or activities. Having said this there was considerable evidence to suggest that a variety of positive immaterial and material effects were gained from interaction with the 'old' industries. 


\section{Agglomeration economies and effects}

As we have seen the relations of the firms to existing industries and clusters proved important to their development. This relates to the third developmental factor we observed which was the effect of location within a large city and the effect of agglomeration economies. The effects of firms being located in industrial agglomerations or large cities have long been discussed (Feldman, 2000; Glaeser, 2000; Storper and Venables, 2002). For example, Glaeser (2000: 84) argues that "cities exists to eliminate the transport costs for people, goods and ideas". In a similar fashion Storper and Venables discuss why people and economic activities tend to agglomerate and suggest this is due to the importance of: links between firms; access to markets; dense labour markets; and "localized interactions which promote technological innovation" (Storper and Venables 2002: 4).

Obviously there are some factors making location within a large city or an industrial agglomeration crucial for firms within a particular sector. In the interviews conducted during the research a number of agglomeration or urban aspects frequently arose as important. One important aspect was the density of customers in a city like Stockholm. This was especially important for those firms dealing in products targeted at record companies and those aimed at large consumer markets (such as ring-tones). Though for most of the firms, dealing as they do in niche markets, that Sweden's relatively small population cannot fully support, Stockholm and Sweden were considered as good test beds and initial markets from which to latter pursue international markets.

The city's highly advanced urban infrastructure was also cited as important. Whilst well developed air links to the rest of the world and courier services within the city were frequently referenced it was overwhelmingly the city's technological and telecommunications infrastructure and services that were pointed to as vital for performance. The provision of adequate high speed bandwidth for the distribution of products and contact with customers/clients as well as high quality server providers were also mentioned. Stockholm's advanced mobile telephone and wireless computing networks were particularly important to certain businesses.

Less tangible assets were also commonly referred to and every firm interviewed mentioned the positive influence from just being there, being close to old family and old friends, keeping an eye on local competitors and partners, and having the chance to 'listen' to the local milieu and trying to find out the next big thing. The dominance of Stockholm in Swedish life, the dense fabric of the city and the fact that nearly all the firms were located within walking distance from one another backed up the 
'buzz' (Storper and Venables 2002) surrounding the city itself and around the music and ICT industries. Perhaps more important was that the 'buzz' seemed largely a shallow reflection of a deeper set of social networks: often referred to as 'scenes' by musicians and fans (Kruse, 1993). These networks were commonly based on personal friendships and acquaintances made by firm members during their early careers in the music industry (and to a lesser extent the ICT industry). These networks it appeared should be seen less as diffuse propagators of 'buzzes' and diffuse knowledge/insights and more as structured networks of 'pipelines' (Bathelt, Malmberg and Maskell, 2002) to important gatekeepers, possible clients and collaborators. Especially important to most respondents were that these networks contained 'pipelines' that reach outside the local milieu: social networks were commonly used to get in touch with Swedes working in the music industry outside Sweden or other international professional contacts. Interviewees considered this set of well developed external links equally if not more important than local ones.

Above all agglomeration considerations already mentioned stood the importance of the labour market. As opposed to the traditional image of the ICT-industry the music-industry is predominantly staffed by people with low levels of formal education (Hallencreutz, 2002). One reason for this lack may be the traditional absence of formalized education programmes for the music industry (though a number of university level courses are now available) but in any case it is hard to formalize or teach people core business operations such as spotting [p. 435] hits and the like. Nonetheless, working in the industry for a number of years can be considered a very rigorous, and cut throat, form of vocational training. Those that survive this 'training' can be considered to be highly qualified. In comparison the ICT service industry in Sweden is staffed by people who tend to have high levels of formalized university level education in technical subjects. Due to the success of the industry both at home and abroad these people have become sought after commodities in their own right. Particularly scarce, and exactly the type of staff music-ICT firms need, are people who combine the skills and trainings associated with both industries. In addition to staff it was found that with few exceptions all owners/founders had a background in the music industry. Given the relative scarcity of people well qualified people in either of the industries, and particularly those qualified in both, it is hardly any surprise that all but one firm interviewed cited staff recruitment and retention as their biggest problem but also the most important factor keeping them in Stockholm. It was thought by most that very few cities in the world, and only one in Sweden, could provide them with the type of staff they needed. 
Finally, interview data clearly pointed out that practitioners in these firms (especially the firms that were not direct subsidiaries of larger concerns) most often located in the central areas of Stockholm due to the fact that they have worked and lived there before the company was set up. It was clear that a sense of cosmopolitanism and the choice of different lifestyles on offer were crucial in determining why the individuals we spoke to chose to locate there. Time and time again interviewees stated that it was not an option to move to a different area of Sweden: though some mentioned large foreign cities such as London or New York as possible alternatives. This suggests that the reasons for agglomeration were often as much cultural, environmental and social as an outcome of rational economic location decision-making: a phenomenon found in many other cultural industry settings (Zukin, 1995; Scott, 1997; Caves, 2000; Gibson et al., 2002; Hesmondhalgh, 2002).

\section{New business thinking and modus operandi}

Whilst the firms studied and activities they were involved in were very diverse it was noted that three key organisational or cultural norms characterised their business thinking or modus operandi to the extent that it can be said that these commonalities form a fourth plank in explaining the development of music-ICT in Stockholm.

First, it was observed that all the firms studied and interviewed had consciously developed an international or global export oriented perspective. The fact that most of their products and services were amenable to digital distribution makes them relatively easy to export. But the export orientation most commonly sprang from the perception that Sweden's small domestic market could not fully support their survival; indeed the relatively small domestic market has long forced Swedish music and ICT into being export dependent/oriented. As already mentioned many of the firms client/consumer bases were abroad: principally Germany and the US. In addition those companies that had a high degree of need for specialised technical inputs into product development and operation often preferred to search the world for the best support rather than rely on the closest service provider or partner. Those involved in coding and the design of software that ultimately runs on personal computers commonly looked to California based technical support providers (even where the US firm had a local branch). Expansion overseas was also said to dominate medium term business plans and firms consistently suggested that they viewed the Swedish market as a platform from which to launch overseas expansion. 
However, one was left wondering if the global orientation is not often borne more out of culture than necessity. Most companies heavily rely on local markets, clients and localized forms of revenue and capital even though their stated business aim was global domination. Swedish service industry business culture is often extremely ideologically oriented towards global market success (in particular US market success) and it appeared that even those companies with little or no concrete plan or need to enter the global marketplace saw it as desirable; and indeed a validation that they were a serious business.

The second aspect of this shared modus operandi was a focus on 'community' (e.g. a community of software users or music fans) as a core business concept. In the same way as the virtual instrument manufacturers mentioned earlier cited the building of communities around their core products as a vital tool for product competitiveness and profitability virtually all other firms likewise agreed this to be the key to success. The idea of communities in music is nothing new as fan clubs, fanzines, etc. have long played an important role in securing success and customer loyalty. However, in recent years they have become important in other ways. In particular, in reaction to their perception of the absolutely unenforceable nature of intellectual property rights firms have, as mentioned earlier, attempted through the building of communities not just 'add value' to their products but also to use brand building and customer loyalty to better manage risk arising from the product's inherent instability and immateriality. All those interviewed suggested, however, that this was a very difficult process; the development of which they often took more seriously than the technical elements of ICT innovation analysts traditionally point to as key to competitiveness. Most agreed that in a world of well functioning products [p. 436] it was the symbolic, cultural and communal elements of their product that their performance depended upon.

A third aspect of the 'shared' culture of these firms was a strong sense of independence. This may be the inheritance of the stand-alone against the system attitude often associated with the music industry and indeed the early ICT pioneers. However, this sense of having to do everything yourself was combined with a highly developed idea that network capital was the key to many aspects of business: in particular customer relations and marketing/selling. Government intervention in issues other than helping with vocational training and providing help with export licenses and finding employees were thought by participants to be either not necessary or indeed negative. Such an almost neo-liberal attitude to government and the surrounding institutional structure may be thought to be in 
contrast to mainstream attitudes towards such things found in this historically social democratic country.

\section{Conclusion}

In conclusion, these types of new industrial synergies seemed, to us at least, to say much about the way industrial innovations are formed in an inter-industry and inter-cluster environment. The firms researched were engaged in innovative and evolving business activities but it was their relations to and self-positioning within existing clusters that had one of the most important effects on the development of their individual business models and trajectories. Proximity to or existence within the bounds of a strong competitive cluster certainly had a variety of both material and immaterial effects and though many of these can be considered positive this is not necessarily so. Positioning oneself firmly within the innovation and operational dynamics of an established cluster appeared in these cases to be the most risky strategy. In many ways it was the firms that straddled both which seemed to fare the best as this gave them some degree of isolation from the competitive maelstrom of vested interests and large market movements that existed within the clusters. Of the companies studied that could be said to truly straddle both music and ICT more than half considered that their position in between these clusters - or their double membership of them - to be beneficial (this was clearly stated in interviews). Indeed the research suggested the existence of a set of hyper-flexible firms that attempted to defy being bounded within established sectors. Many of these firms consciously engaged and disengaged across 'cluster boundaries' where and when it seemed strategically, commercially or financially relevant. One could indeed suggest that this case begs the question of whether innovation and adaptation of new technologies in fact occurs best in a cross-or inter-cluster context?

Secondly, our suggestion that in Stockholm there has been a growth of a music service economy suggests to us much about the future workings and shape of the music industry and music centres. Whilst in many ways this set of music service firms and activities are heavily related and tied to the 'traditional' music industry in Stockholm they do not entirely depend upon the traditional focus on the mass production of recorded music. Indeed a number of the firms studied depend less and less on the domestic music scene and have become successful service providers to a range of global clients and consumers who are demanding everything from mixing and song-writing to samples and virtual 
instruments. This carries with it the possibility of both strengthening the existing music industry/cluster and indeed becoming an export oriented industry quite separate from the traditional notion of exporting domestic artistes to foreign ears. Indeed interviews with 30 executives in US record companies and distributors (carried out by one of the authors for a different project) found that for many in the music industry Stockholm is now equally known for its role as a service provision centre as for its performers.

The evolution of a music services sector in Stockholm we argue is suggestive and indicative of a deeper shift in the music industry: the development of a post-industrial (and post-MP3) musical economy where services and related products around the core music make the money and reputation for musical centre and indeed the industry as a whole. The type of activities we looked at in this project and paper support this claim; however, we are not suggesting that ring-tones and the specific firms and activities listed earlier are the epicentre for this shift. Rather we suggest they are illustrative of a wider technologically mediated set of phenomena and emerging activities that are part of a deep shift in the industry: other technologies that we did not find many examples of in Stockholm may in fact prove much more important (such as 'music recommendation' software or new music filtering services: see (Brindley, 2000). This shift is being forced upon the industry by declining sales in CDs and an increasingly uncertain and difficult copyright environment. The music industry has always relied on two things on which to make its money: the selling of copyrighted sounds and performances; and the building of brands. In the past market conditions and people's consumption patterns meant that the industry could be hugely profitable by concentrating on selling recorded music: i.e. intellectual property embedded in plastic/vinyl. The value of the brand aspect - for instance the global recognition stars command - was used by the industry merely as a tool to sell the plastic. Whilst record companies invested enormous sums of money into building a brand up around a performer or group it has always been the performer/group that has sold and profited from the brand: for instance by getting revenue Ip. 437] from live performances, advertising, books, careers in film, etc.. The music industry is starting to realise that these brands, it provides the capital required to build, are increasingly much more lucrative than the music itself. Historically the music industry has been poor at exploiting brand potential: though there have been a few examples of bands that made more from T-shirts than music.

"Those big artists have taken many years and maybe a couple of billion or in any case several hundred million [Swedish crowns] in investment before they break even. And then the artists have on the back of all this building work and investment become brands and then 'the brand' 
has gone direct to the market and not given a damn about the record company, like Madonna who had a concert in London with Microsoft MSN streamed. And she got nine million dollars for it. That won't be allowed in the future." Ludvig Werner, Fame Studios AB, 28 August 2002.

Companies have recently started, in return for making them global stars, signing artistes to deals which include not only albums but also control over revenue from touring, publishing and merchandising: the most recent example of which was EMI's reportedly US\$100 million deal with the singer Robbie Williams in October 2002. Whilst such costly and high profile deals may eventually mean increased profits for a few of the largest record companies, generally firms in the music industry could learn much from firms working on crossing music and ICT about working in an environment where enforceable or effective intellectual property regimes cannot be counted upon. The firms we studied are pioneering and showcasing methods for building added-value to products and new product areas and distribution channels (such as ring-tones, streaming, and multimedia). Their focus on building community and added enticements onto products, new channels for distribution and new revenue sources from associated services seems key to commercial survival in a post-industrial musical economy. 


\section{References}

Alderman, J., 2002. Sonic boom : Napster, MP3 and the new pioneers of music. London, Fourth Estate. Alexander, P., 1996. Entry barriers, release behaviour, and multi-product firms in the popular music recording industry. Review of Industrial Organization 9, 85-98.

Alexander, P. J., 2002. Peer-to-peer file sharing: The case of the music recording industry. Review of Industrial Organization 20(2), 151-161.

Almquist, K., Engström, M., Olausson, K., 1999. Blandade Upplevelser: an förstudie om svensk upplevelseindustris möjligheter, med förslag till åtgärder - först rapport. Stockholm, Stiftelsen för Kunskaps- och Kompetensutveckling.

Almquist, K., Engström, M., Olausson, K., 2000. Blandade Upplevelser: an förstudie om svensk upplevelseindustris möjligheter, med förslag till åtgärder - rapport, andra upplagan. Stockholm, Stiftelsen för Kunskaps- och Kompetensutveckling.

Asheim, B., 1999. Interactive learning and localised knowledge in globalising learning economies. GeoJournal 49, 345-352.

Banks, M., Lovatt, A., O’Connor, J., Raffo, C., 2000. Risk and trust in the cultural industries. Geoforum 31, 453-464.

Bathelt, H., Malmberg, A., Maskell, P., 2002. Clusters and Knowledge: Local buzz, global pipelines and the process of knowledge creation. Presented at Second International Symposium on "knowledge and Space", Heidelberg, September.

Bell, D., 1974. The Coming of Post-Industrial Society. London, Heinemann.

Berggren, C., 2000. The Embeddedness of Industrial Clusters. The Case of the Nordic telecom industry. Presented at Entrepreneurship, Firm Growth and Regional Development in the new Economic Geography, Uddevalla, Sweden, 15-17 June.

Birkinshaw, J., 2000. The information technology cluster in Stockholm: changes from 1997 to 2000 and prospects for continued growth. Stockholm, Invest in Sweden Agency.

Brail, S., Gertler, M., 1999. The Digital Economy - Emergence and evolution of Toronto's multimedia cluster. Multimedia and Regional Economic Restructuring. Braczyk, H.-J., Fuchs, G., Wolf, H.-G. London, Routledge: 97-130.

Braunerhjelm, P., Carlsson, B., 1999. Industry clusters in Ohio and Sweden 1975-1995. Small Business Economics 12, 279-93.

Braunerhjelm, P., Helgesson, C., 2003. Madonna and the Music Miracle: a study of the music cluster in Stockholm. Stockholm, SNS Förlag.

Brindley, P., 2000. New musical entrepreneurs. London, Institute for Public Policy Research.

Burnett, R., 1993. The popular music industry in transition. Popular Music and Society 17, 87-114.

Burnett, R., 1996. The Global Jukebox: The International Music Industry. London, Routledge.

Burnett, R., 1997. Den svenska musikindustrins export 1994-95. Stockholm, ExMS.

Caves, R., 2000. Creative Industries: contracts between art and commerce. Cambridge, Mass., Harvard University Press.

Choi, C. J., Hilton, B., 1995. Globalization, Originality, and Convergence in the Entertainment Industry. Advances in Applied Business Strategy. Foster, L. Greenwich, CT, JAI Press.

Christiansen, M., 1995. Cycles in symbolic production? A new model to explain concentration, diversity and innovation in the music industry. Popular Music 14, 55-93.

Clark, G., 1998. Stylised Facts and Close Dialogue: Methodology in Economic Geography. Annals of the Association of American Geographers 88(1), 73-87.

Cooper, J., Harrison, D. M., 2001. The social organization of audio piracy on the Internet. Media Culture \& Society 23(1), 71-+.

Cusic, D., 1996. Music in the Market. Bowling Green OH, Bowling Green State University Popular Press.

England, K., 1994. Getting personal: reflexivity, positionality and feminist research. Professional Geographer 45, 307-17.

European Commission, Federation of Austrian Industry in Styria, 1999. Cluster-building: A Practical Guide. Brussels, DG XVI. 
Feldman, M., 2000. Location and innovation: the new economic geography of innovation, spillovers, and agglomeration. The Oxford Handbook of Economic Geography. Clark, G., Feldman, M., Gertler, M. Oxford, Oxford University Press.

Firth, S., 1992. The industrialisation of popular music. Popular Music and Communication. Lull, J. Newbury Park, CA, Sage.

Forss, K., 1999. Att ta sig ton: om svensk musikexport 1974-1999. Ds 1999:28. Stockholm, Fritzes.

Forss, K., 2001. The Export of the Swedish Music Industry: an update for the year 2000. Stockholm, Export Music Sweden.

Forss, K., Podolieva, K., 2002. The Export of the Swedish Music Industry 2001. Stockholm, Export Music Sweden.

Frith, S., 1991. Knowing one's place: the culture of cultural industries. Cultural Studies from Birmingham 1, 135-155.

Frith, S., 1993. The Industrialisation of Popular Music. Popular Music and Communication. Lull, J. Beverly Hills, CA, Sage.

Gibson, C., Murphy, P., Freestone, R., 2002. Employment and socio-spatial relations in Australia's cultural economy. Australian Geographer 33(2), 173-189.

Glaeser, E., 2000. The New Economics of Urban and Regional Growth. The Oxford Handbook of Economic Geography. Clark, G., Feldman, M., Gertler, M. Oxford, Oxford University Press: 83-98.

Gordijn, J., Akkermans, H., Vliet, H. v., Paalvast, E., 2000. Selling Bits: a matter of creating consumer value. Electronic Commerce and Web Technologies, Proceedings Lecture Notes in Computer Science 1875, 48-62.

Grant, R., 1996. Prospering in dynamically-competitive environments: organizational capability as knowledge integration. Organization Science 7, 375-387.

Gronow, P., 1983. The record industry: the growth of a mass medium. Popular Music 3, 53-75.

Hallencreutz, Lundequist, P., Malmberg, A., 2003 (forthcoming). Local embeddedness and international competitiveness: the case of the Swedish music cluster. The Institutions of Local Development. Amin, A., Goglio, S., Sforzi, F.

Hallencreutz, D., 2002. Populärmusik, kluster och industriell konkurrenskraft: an ekonomiskgeografisk studie av svensk musikindustri. Uppsala, Kulturgeografiska institutionen.

Hallencreutz, D., Lundequist, P., 2001. Making knowledge funky: localised learning and competitive SMEs in the Swedish music industry. Presented at Association of American Geographers Annual Conference, New York, 28 Febuary.

Hallencreutz, D., Lundequist, P., Malmberg, A., 2000. Production of popular music: on the industrial geography of the Swedish music cluster. Nordisk Samhällgeografisk Tidskrift 30, 37-59.

Haring, B., 2000. Beyond The Charts: MP3 and the Digital Music Revolution. Los Angeles, JM Northern Media LLC.

Hesmondhalgh, D., 1996. Flexibility, post-Fordism and the music industries. Media, Culture and Society 18, 469-488.

Hesmondhalgh, D., 2002. The Cultural Industries. London, Sage.

Hirsch, P., 1992. Globalization of Mass Media Ownership. Communication Research 19 (6: Special issue).

IFPI (International Federation of the Phonographic Industries), 2001. The Recording Industry in Numbers 2001. London, IFPI.

IFPI (International Federation of the Phonographic Industries), 2003. The Recording Industry World Sales 2002. London, IFPI.

Jansson, J., 2000. Musikindustri I Hultsfred och Malmö. En studie av två lokala produktions miljöer. Arbetsrapporter, 395. Uppsala, Kulturgeografiska institutionen, Uppsala universitet.

Johansson, S., 2000. TIME - företag I Stockholms län: tillväxt och lokalisering av företagens verksamhetstyper 1990-1999. Stockholm, TIME.

Jones, S., 2002. Music that moves: Popular music, distribution and network technologies. Cultural Studies 16(2), 213-232.

Kretschmer, M., Klimis, G. M., Wallis, R., 2001. Music in electronic markets - An empirical study. New Media \& Society 3(4), 417-441.

Kruse, H., 1993. Subcultural identity in alternative music culture. Popular Music 12(1), 33-41.

$\mathrm{Ku}, \mathrm{R}$. S. R., 2002. The creative destruction of copyright: Napster and the new economics of digital technology. University of Chicago Law Review 69(1), 263-324.

Leyshon, A., 2001. Time - space (and digital) compression: software formats, musical networks, and the reorganisation of the music industry. Environment and Planning A 33, 49-77. 
Leyshon, A., 2003 Forthcoming. Scary Monsters? software formats, peer-to-peer networks and the spectre of the gift. Environment and Planning D: Society and Space 21.

Leyshon, A., Matless, D., Revill, G., (Eds.) 1998. The Place of Popular Music. New York, Guildford Press.

Lopes, P., 1992. Innovation and diversity in the popular music industry, 1969-1990. American Sociological Review 57, 56-71.

Lundequist, P., 2002. Spatial Clustering and Industrial Competitiveness: Studies in Economic Geography. Uppsala, Kulturgeografiska institutionen.

Lundequist, P., Power, D., 2002. Putting porter into practice? Practices of regional cluster building: Evidence from Sweden. European Planning Studies 10(6), 685-704.

Lundvall, B.-Å. 1992. National Systems of Innovation: towards a theory of innovation and interactive learning. London, Pinter.

Malm, K., Wallis, R., 1992. Media Policy and Music Activity. London, Routledge.

Malmberg, A., 2002. Klusterdynamik och regional näringslivsutveckling - begreppsdiskussion och forskningsöversikt. Stockholm, ITPS (Institutet för Tillväxtpolitiska Studier).

Malmberg, A., Maskell, P., 2002. The elusive concept of localization economies: towards a knowledge-based theory of spatial clustering. Environment and Planning A 34(3), 429-449.

Malmberg, A., Power, D., 2003 forthcoming. On the role of global demand in local innovation processes. Rethinking Regional Innovation and Change. Shapiro, P., Fuchs, G. Dordrecht, Kluwer Academic Publishers.

Malmberg, A., Sölvell, Ö., Zander, I., 1996. Spatial clustering, local accumulation of knowledge and firm competitiveness. Geografiska Annaler 78B.

Martin, R., Sunley, P., 2003. Deconstructing clusters: chaotic concept or policy panacea? Journal of Economic Geography 3(1), 5-35.

McCourt, T., Rothenbuhler, E., 1997. SoundScan and the consolidation of control in the popular music industry. Media Culture \& Society 19(2), 201-\&.

McDowell, L., 1992. Multiple Voices: speaking from inside and outside 'the project'. Antipode 24(1), 56-72.

Menn, J., 2003. All the Rave: The Rise and Fall of Shawn Fanning's Napster. New York, Crown Business.

Merriden, T., 2001. Irresistible Forces : The Business Legacy of Napster and the Growth of the Underground Internet. Chichester, Capstone/Wiley.

Negus, K., 1998. Cultural production and the corporation: musical genres and the strategic management of creativity on the US recording industry. Media, Culture and Society 20, 359379.

Negus, K., 1999. Music Genres and Corporate Cultures. London, Routledge.

Nelson, R., (Ed.) 1993. National Innovation Systems: a comparative analysis. Oxford, Oxford University Press.

Nonaka, I., 1994. A dynamic theory of organizational knowledge creation. Organization Science 5, 1437.

NUTEK (Närings- och teknikutvecklingsverket), 2001. Innovative Clusters in Sweden: practical lessons from regional cluster-building. Stockholm, NUTEK Klustergruppen (Swedish Cluster Focus Group).

OECD, 1999. Boosting innovation: the cluster approach. Organisation for economic co-operation and development. Paris, OECD.

OECD, 2001. Innovative Clusters: drivers of national innovation systems. Paris, OECD.

OECD (Organisation for Economic Co-operation and Development), 2000. Measuring the ICT sector. Paris, OECD.

OECD (Organisation for Economic Co-operation and Development), 2002. Measuring the Information Economy 2002. Paris, OECD.

Peterson, R., Berger, D., 1996. Measuring industry concentration, diversity and innovation in popular music. American Sociological Review 61, 175-178.

Porter, M., 1990. The Competitive Advantage of Nations. New York, The Free Press.

Porter, M., 1998. Clusters and the new economics of competition. Harvard Business Review Nov-Dec, 77-90.

Porter, M., 2001. Clusters of Innovation: regional foundations of U.S. competitiveness. Washington, Council on Competitiveness.

Power, D., 2002. "Cultural industries" in Sweden: An assessment of their place in the Swedish economy. Economic Geography 78(2), 103-127. 
Power, D., 2003. Final Report: Behind the music - Profiting from Sound: A Systems Approach to the Dynamics of Nordic Music Industry. Oslo, Nordic Industrial Fund - Centre for Innovation and Commercial Development. http://www.step.no/music/Report.htm

Power, D., Hallencreutz, D., 2002. Profiting from creativity? The music industry in Stockholm, Sweden and Kingston, Jamaica. Environment and Planning A 34(10), 1833 - 1854.

Power, D., Malmberg, A., 2003. (How) Do clusters create knowledge? Presented at DRUID Summer Conference 2003, Copenhagen. http://www.druid.dk/conferences/summer2003/Papers/MALMBERG_POWER.pdf

Pratt, A., 2000. New Media, the New Economy and New Spaces. Geoforum 31, 425-436.

Sadler, D., 1997. The global music business as an information industry: reinterpreting economies of culture. Environment and Planning A 29, 1919-1936.

Sandberg, A. 1999. The multimedia industry in Sweden and the emerging Stockholm cluster. Multimedia and Regional Economic Restructuring. Braczyk, H.-J., Fuchs, G., Wolf, H.-G. London, Routledge.

Schoenberger, E., 1991. The Corporate Interview as a Research Method in Economic Geography. Professional Geographer 43(2), 180-189.

Scott, A., 1997. The cultural economy of cities. International Journal of Urban and Regional Research 2, 323-329.

Scott, A., 1999a. The US recorded music industry: on the relations between organization, location, and creativity in the cultural economy. Environment and Planning A 31, 1965-1984.

Scott, A., 1999b. The cultural economy: geography and the creative field. Media, Culture and Society $21,807-817$.

Scott, A., 2000. The Cultural Economy of Cities: essays on the geography of image-producing industries. London, Sage.

Shapiro, D., Abercrombie, N., Lash, S., Lury, C., 1992. Flexible specialisation in the cultural industries. Regional Development and Contemporary Industrial Response. Ernste, H., Meier, V. London, Belhaven.

Shirky, C., 2001. Sonic boom: MP3, Napster, and the new pioneers of music. Harvard Business Review 79(2), 143-148.

Smith, S., 1993. Who's Talking/ Who's Talking Back?: the subject of personal narrative. Signs 18(2), 392-407.

Statens Kulturråd, 1998. Kulturen i siffror - Kulturen i ett regionalt perspektiv. Trelleborg, Skogs Botryckeri.

Statens Kulturråd, 2000. Om 2000 Världen: Kulturrådets omvärldsanalys. Trelleborg, Berlings Skogs.

STIM (Svenska Tonsättares Internationella Musikbyrå), 2001. STIM Annual Report 2001. Stockholm, STIM.

Storper, M., Venables, A., 2002. Buzz: the economic force of the city. Presented at DRUID Summer Conference on 'Industrial Dynamics of the New and Old Economy - who is embracing whom?' Copenhagen/Elsinore, 6-8 June.

Tang, P., 1998. How electronic publishers are protecting against piracy: Doubts about technical systems of protection. Information Society 14(1), 19-31.

Wallis, R., 1990. Internationalization, Localization and Integration - The changing structure of the music industry and its relevance for smaller countries and cultures. Göteborg, The Department of Journalism and Mass Communication, Göteborg University.

Wallis, R., Malm, K., 1984. Big Sounds from Small Peoples: The Music Industry in Small Countries. London, Constable.

Wallis, R., Malm, K., 1990. The Implications of Structural Changes in the Music Industry for Media Policy and Music Activity. Popular Music Research. Roe, K., Carlsson, U. Göteborg, Göteborg University, Nordicom-Sweden 1-2.

White, A., Coronado, R., 2000. Networks.com - a study of interlocking directorates in the Swedish internet industry. International Business, Stockholm School of Economics.

Zook, M., 2000. The Web of Production: The economic geography of commercial internet content production in the United States. Environment and Planning A 32, 411-426.

Zukin, S., 1995. The Culture of Cities. Oxford, Blackwell. 